\title{
RESPONS SPEKTRA GEMPA BUMI DI BATUAN DASAR KOTA BITUNG SULAWESI UTARA PADA PERIODE ULANG 2500 TAHUN
}

\author{
Guntur Pasau ${ }^{1)}$ \\ ${ }^{1)}$ Program Studi Fisika FMIPA Universitas Sam Ratulangi Manado, 95115 \\ e-mail: pasaujunior@gmail.com
}

\begin{abstract}
ABSTRAK
Telah dilakukan analisis respons spektra gempa bumi di Kota Bitung Sulawesi Utara menggunakan teori probabilitas total. Penelitian ini bertujuan untuk menentukan percepatan gempa maksimum di batuan dasar Kota Bitung pada probabilitas $2 \%$ terlampaui dalam 50 tahun atau setara dengan periode ulang 2500 tahun. Resiko gempa dianalisis menggunakan bantuan software PSHA-USGS 2007. Hasil analisis menunjukkan bahwa percepatan tanah maksimum di batuan dasar Kota Bitung dan sekitarnya sebesar 0,7 g dengan kontribusi terbesar berasal dari penunjaman lempeng laut Maluku ke arah barat. Kejadian gempa rata-rata tiap tahun sekitar 5-6 kali dan sebagian besar disebabkan oleh sumber gempa dangkal dan sumber gempa dalam.
\end{abstract}

Kata kunci: batuan dasar, gempa, respons spektra

\section{THE RESPONSE OF SPECTRAL EARTHQUAKE ON THE BEDROCK OF BITUNG CITY NORTH SULAWESI DURING 2500-YEAR-RETURN PERIOD}

\begin{abstract}
The response of spectral earthquake was analyzed on the bedrock Bitung North Sulawesi using the theory of total probability. This research aimed to determine the peak of ground acceleration on this bedrock using exeeded probability of $2 \%$ during 50 -year-return period (equivalent to 2500-year-return period). Seismic risk was analyzed using software of PSHA-USGS 2007. The analysis result indicated that the maximum ground acceleration on this bedrock and surrounding areas of $0.7 \mathrm{~g}$. The biggest contribution to this acceleration came from the subduction of Maluku sea plate to the west. The average incidence of the earthquake was about 5-6 times per year and most of the resulted from the sources of shallow and deep earthquakes.
\end{abstract}

Keywords: bedrock, earthquakes, spectral respons

\section{PENDAHULUAN}

\section{Latar Belakang}

Kota Bitung terletak pada posisi geografis diantara $1^{0} 23^{\prime} 23^{\prime \prime}-1^{0} 35^{\prime} 39^{\prime \prime} \mathrm{LU}$ dan $125^{\circ} 1^{\prime} 43^{\prime \prime}$ ' $-125^{\circ} 18^{\prime} 13^{\prime}$ 'BT (Gambar 1). Dilihat dari kondisi tektoniknya Bitung dipengaruhi oleh subduksi Sulawesi utara (Minahasa trench) subduksi ganda (double subduction) Laut Maluku dan penunjaman lempeng laut Filipina. Dengan kondisi terebut diatas sehingga Bitung sangat rawan akan bencana gempa bumi dan tsunami. Berkaitan dengan kondisi tersebut, salah satu upaya yang bisa dilakukan untuk meminimalkan dampak bencana gempa adalah menyiapkan semua prasarana yang dibangun di Bitung dan sekitarnya yang tahan terhadap goncangan gempa bumi. Salah satu upaya mitigasi tersebut hanya dapat dilakukan dengan cara mengetahui karakteristik gempa sehingga kita dapat memodelkan sumber gempa untuk menentukan percepatan gempa di wilayah yang ditinjau.

Respon spektra gempa bumi merupakan suatu hal yang diperlukan untuk menunjukkan tingkat resiko gempa suatu wilayah terutama untuk wilayah dengan tingkat aktifitas kegempaan yang tinggi. Respon spectra ini berupa suatu kurva hazard yang merupakan peta zonasi percepatan maksimum dibatuan dasar untuk perioda ulang 2500 tahun yang dibuat berdasarkan hasil analisis seismic hazard probabilistik (Probabilistic seismic hazard analysis/PSHA) dengan menggunakan model sumber gempa tiga dimensi (3-D). Studi di Kota Bitung dan sekitarnya dilakukan karena 
mengingat daerah ini aktivitas seismotektoniknya cukup tinggi sebagai akibat dari penunjaman yang sangat kompleks dari penunjaman lempeng laut Maluku, lempeng Filipina dan subduksi Sulawesi Utara.

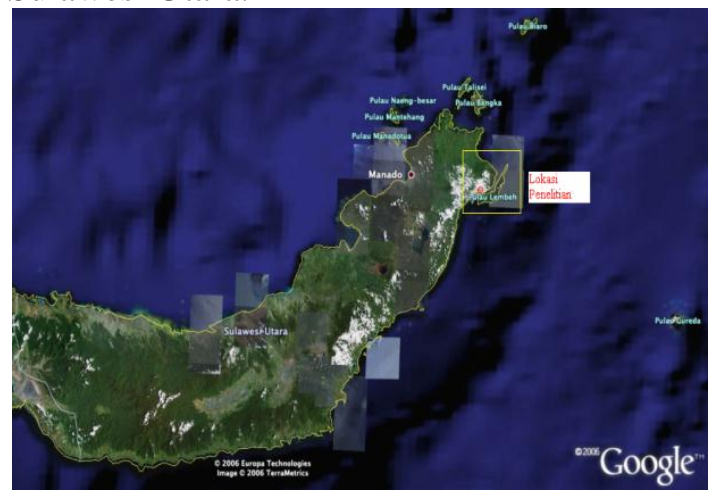

Gambar 1. Peta Lokasi Daerah Penelitian.

\section{Ruang Lingkup}

Ruang lingkup penelitian meliputi wilayah Kota Bitung dan sekitarnya. Data gempa yang digunakan hanya gempa utama (main sock) yang bebas dari gempa susulan dengan magnitudo $\geq 5 \quad \mathrm{Mw}$ serta mempunyai kedalaman maksimum $300 \mathrm{~km}$.

\section{Tujuan}

Penelitian ini bertujuan untuk mengetahui respon spketra gempa di Kota Bitung Sulawesi Utara pada probabilitas $2 \%$ terlampaui dalam 50 tahun atau pada periode ulang 2500 tahun. Dari hasil plot respon spektra dapat diketahui percepatan maksimum goncangan gempa dan sumber gempa apa saja yang mempunyai hazard yang signifikan di wilayah yang ditinjau.

\section{TINJAUAN PUSTAKA}

\section{Kondisi Tektonik Bitung}

Bagi beberapa ilmuan khususnya ahli geologi dan ahli kebumian, Pulau Sulawesi tidak hanya menarik sebagai objek penelitian karena mempunyai himpunan bebatuan dari segala jenis dan tingkatan umur yang kompleks, mempunyai beberapa sumberdaya alam yang melimpah, tetapi Sulawesi juga mempunyai kondisi kegempaan yang sangat fenomenal. Pulau Sualwesi merupakan salah satu pulau yang telah mengalami suatu proses tektonik yang sangat kompleks dalam waktu geologi. Bentuk pulau ini yang menyerupai huruf $\mathrm{K}$ setidaknya memberikan gambaran bahwa pulau ini mempunyai karakteristik berbeda khususnya kondisi geologi.

Kondisi pulau Sulawesi yang dibentuk oleh interaksi setidaknya tiga lempeng bumi; yaitu lempeng Pasifik dengan pergerakan relatif ke barat, lempeng IndoAustralia yang bergerak relatif ke utara dan lempeng Eurasia yang relatif stabil, tentu sangat potensial untuk terjadi gempa akibat interaksi ketiga lempeng diatas tadi. Sehingga gempa yang terjadi dibeberapa tempat yang ada di Sulawesi Selatan bukan merupakan hal yang luar biasa, tetapi merupakan sebuah keniscayaan.

Kota Bitung yang secara geologis sangat dipengaruhi oleh Zona tumbukan ganda laut Maluku yang sangat kompleks dan Subduksi Sulawesi Utara. Zona tumbukan laut Maluku sebelah utara busur Banda merupakan zona tumbukan antara busur kepulauan yaitu busur Sangihe di sebelah barat dan busur Halmahera di sebelah timur. Di bawah zona tumbukan Laut Maluku yang memanjang dalam arah utara-selatan ini telah diamati adanya suatu penunjaman slab dari lempeng laut Maluku dengan konfigurasi penunjaman yang sangat unik, dimana slab dari lempeng yang sama menunjam ke dua arah yaitu barat dan timur berbentuk seperti U terbalik (Widiyantoro, 2007).

Sementara Subduksi Sulawesi Utara (Minahasa Trench) yang oleh ahli kebumian diinterpretasikan merupakan zona subduksi konvergen antara Laut Sulawesi dan Lengan Utara Sulawesi (Hamilton, 1979). Zona subduksi Sulawesi Utara termasuk kedalam sistim penunjaman yang relatif tua (dying subduction) yang robekannya berkembang ke arah timur sepanjang tepian utara Sulawesi. Penunjaman Sulawesi Utara menyusup dengan sudut kemiringan sekitar $14^{0}$ dan zone benioff menunjam sampai kedalaman 170$180 \mathrm{~km}$, dengan sudut kemiringan sekitar $45^{\circ}$.

\section{Resiko Gempa}

Resiko gempa adalah kemungkinan terlampauinya (probability of exceedance) suatu gempa dengan intensitas tertentu selama suatu masa guna bangunan. Resiko gempa ini dapat dinyatakan dalam bentuk,

$$
\begin{aligned}
& \begin{array}{l}
R_{n}=1-\left(1-R_{a}\right)^{N} \text { ? } \\
\text { dimana, }
\end{array} \\
& R_{n}=\text { resiko gempa } \\
& R_{a}=\text { resiko tahunan }=1 / T
\end{aligned}
$$


$N=$ masa guna bangunan

$T=$ perioda ulang gempa

Saat ini, peraturan bangunan internasional terbaru untuk bangunan tahan gempa menggunakan peta hazard kegempaan dengan resiko terlampaui sebesar $10 \%$ dan 2 $\%$ selama masa guna bangunan 50 tahun (10\% and $2 \%$ probability of exceedance in 50 years) atau periode ulang gempa 475 tahun dan 2475 tahun.

\section{Identifikasi Sumber- Sumber Gempa}

Identifikasi sumber gempa diperlukan untuk mengetahui sumber-sumber gempa yang memiliki potensi untuk menghasilkan kejadian gempa yang mempengaruhi suatu daerah tertentu. Suatu sumber gempa menggambarkan suatu area pada sebuah lempeng yang memiliki karakteristik aktivitas gempa yang berbeda terhadap lempeng disekitarnya. Suatu sumber gempa dapat diidentifikasi berdasarkan datadata geologi, seismologi dan geofisika (Irsyam, 2008). Berdasarkan data-data struktur geologi yang digabungkan dengan data-data kejadian gempa historis, maka dapat diperkirakan tingkat tegangan tektonik yang terjadi. Zona sumber gempa di Indonesia dapat diklasifikasikan dalam tiga jenis berdasarkan mekanismenya, yaitu zona subduksi, zona transformasi (shallow crustal) dan zona diffuse seismicity. Seluruh zona sumber gempa tersebut tergolong aktif tetapi hanya beberapa sumber gempa saja yang pernah menghasilkan kejadian gempa dengan $M w>8,5$ dalam kurun waktu dua abad terakhir.

\section{Parameter Hazard Kegempaan}

Parameter hazard kegempaan dapat menunjukkan aktifitas kegempaan pada suatu wilayah. Parameter hazard kegempaan yang digunakan dalam analisis adalah : recurrence rate, magnitude maksimum, slip rate dan fungsi atenuasi. Sebelum melakukan analisis hazard kegempaan, perlu dilakukan evaluasi terhadap seluruh data kejadian gempa yang pernah terjadi. Selanjutnya dilakukan pengumpulan dan pengolahan data gempa, pembuatan model zona sumber gempa, perhitungan $b$-value dan annual rate, penentuan magnitude maksimum dan slip rate, serta pemilihan fungsi atenuasi.

\section{Analisis Resiko Gempa}

Analisis resiko gempa dilakukan dengan menerapkan teori probabilitas total yang diusulkan oleh Mc Guire (1976). Teori ini mengasumsikan magnitudo gempa $M$ dan jarak $R$ sebagai variabel acak independen yang menerus. Dalam bentuk umum teori probabilitas total ini dapat dinyatakan sebagai berikut:

$$
\begin{aligned}
& P[I \geq i]= \\
& \iint_{r m} P[I \geq i \mid m \text { dan } r] f_{M}(m) f_{R}(r) d m d r \ldots
\end{aligned}
$$

dimana :

$f_{M} \quad$ : fungsi distribusi dari magnitudo

$f_{R}$ : fungsi distribusi dari jarak hiposenter $P[I \geq i \mid m$ dan $r]$ : probabilitas bersyarat dari intensitas $I$ yang melampaui nilai i pada suatu lokasi yang ditinjau untuk kejadian gempa dengan magnitudo $M$ dan jarak hiposenter $R$.

\section{METODOLOGI PENELITIAN}

\section{Pengumpulan dan Pengolahan Data Gempa}

Langkah awal yang diakukan adalah mengumpulkan data sumber gempa dari berbagai katalog gempa seperti USGS dan ANSS selama selang pengamatan dari tahun 1963-2010. Data-data yang berasal dari katalog gempa tersebut perlu dikoreksi dan diproses dengan menggunakan prinsipprinsip statistik sebelum digunakan dalam analisis untuk mengurangi bias dan mendapatkan hasil yang optimal. Langkah selanjutnya adalah melakukan penyeragaman skala magnitudo kedalam skala moment magnitude $(M w)$ dengan menggunakan rumusan yang diusulkan oleh Scrodilis (2006). Data-data yang telah mempunyai skala magnitudo yang sama kemudian diplot seperti pada Gambar 2 dengan menggunakan bantuan software ZMAP ver 6.0 under Mathlab (Wiemar, 2001). 


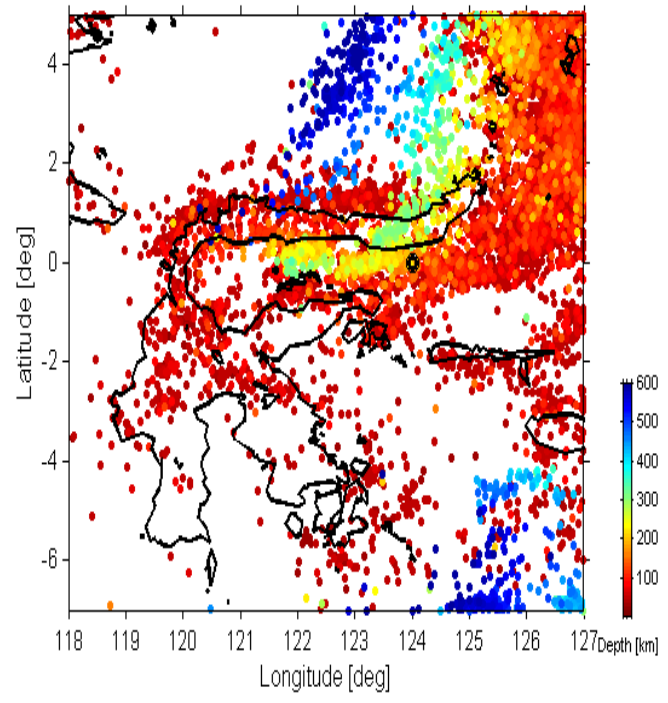

Gambar 2. Data Hiposenter Gempa Pulau Sulawesi dari tahun 1963-2010 (Sumber Data Kompilasi USGS dan ANSS)

Selanjutnya adalah melakukan sortir data untuk menentukan gempa utama (mainsock) yang bebas dari gempa-gempa ikutan (foresock dan aftersock). Pemisahan kejadian gempa utama dilakukan dengan menggunakan kriteria empiris yang diajukan oleh Gardner dan Knopoff (1974). Untuk analisis kelengkapan data gempa digunakan metoda yang diusulkan oleh Stepp (1973). Kejadian gempa dari gabungan katalog tersebut meliputi area mulai $118^{\circ} \mathrm{BT}$ hingga $127^{\circ} \mathrm{BT}$ dan $7^{\circ} \mathrm{LS}$ hingga $5^{\circ} \mathrm{LU}$, dan data gempa lengkap dengan magnitude lebih besar atau sama dengan 5 seperti yang tampilkan pada Gambar 3.

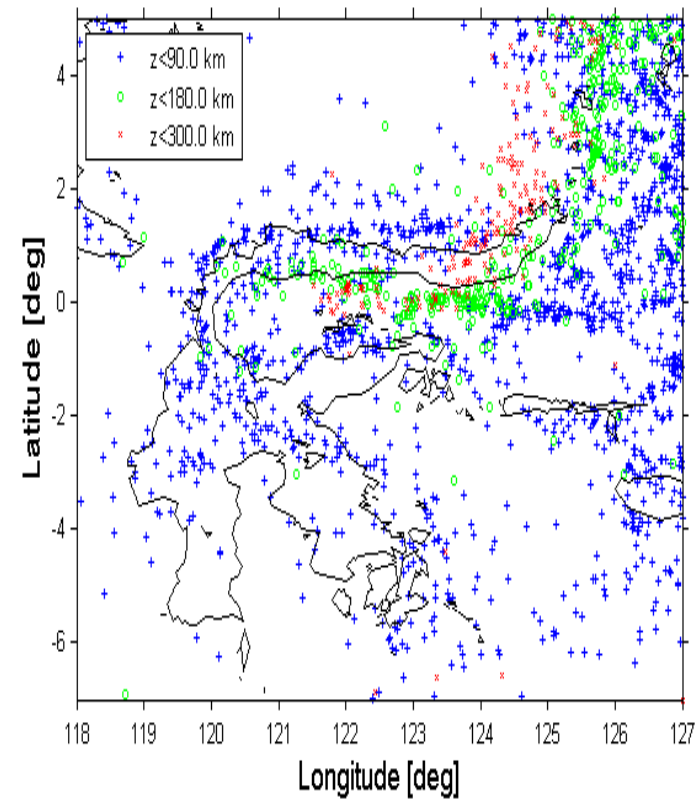

Gambar 3. Data Hipocenter gempa utama (mainsock)
Setelah gempa utama ditentukan maka dilakukan analisis hazard kegempaan menggunakan software PSHA-USGS 2007 untuk menentukan spektra analisis berupa kurva hazard gempa.

\section{Pemodelan Zona Sumber Gempa}

Pada studi ini, zona sumber gempa terbagi atas zona dangkal (shallow) dan zona dalam (deep), zona megathrus di sekitar subduksi Sulawesi Utara dan penunjaman Laut Maluku serta zona ssesar (fault) di pulau Sulawesi. Pemodelan zona sumber gempa ditentukan dengan menganalisa sudut penunjaman pertemuan lempeng yang ditujukan untuk memisahkan sumber gempa yang berbeda jenis mekanismenya yang terletak pada area yang sama. Pola penyebaran titik-titik hypocenter gempa disepanjang pola tektonik dapat diperkirakan dengan membagi zona sumber gempa tersebut menjadi beberapa segmen dan mengambil potongan melintang distribusi epicenter sumber gempa pada setiap segmen tersebut. Parameter $a-b$ didapatkan dari pengelompokan data berdasarkan area sumber gempa dan jenis mekanismenya, dan ditentukan dengan menggunakan model Guttenberg-Richter recurrent relationship (Gutenberg dan Richter, 1944).

\section{HASIL DAN PEMBAHASAN}

Hasil analisis probabilitas seismik hazard berupa respon spektra pada probabilitas $2 \%$ terlampaui dalam 50 tahun atau pada periode ulang 2500 tahun untuk Kota Bitung Sulawesi Utara disajikan dalam bentuk kurva hazard. Hasil analisis kurva hazard adalah merupakan hubungan antara laju kejadian pertahun (annual rate of exceedance) terhadap besar hazard (percepatan gerakan tanah akibat gempa) yang terjadi. Dari grafik kurva hazard kita dapat mengetahui kontribusi masing-masing sumber gempa yang sangat signifikan dapat terjadi dan sangat rentan terhadap suatu site yang ditinjau. Selain itu dari kurva hazard juga dapat menunjukkan dan menjelaskan mengenai kejadian rata-rata suatu gempa dalam setahun.

Pada kurva hazard yang dihasilkan di batuan dasar di Kota Bitung seperti yang ditampilkan pada Gambar 4. 


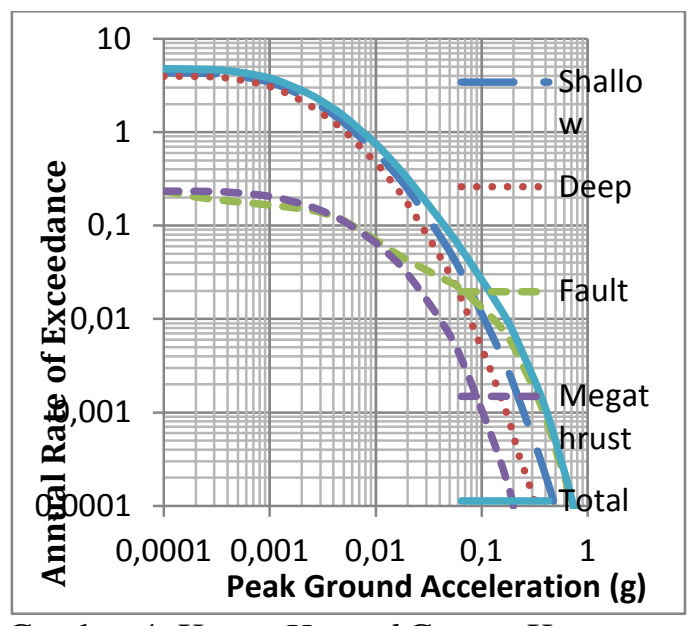

Gambar 4. Kurva Hazard Gempa Kota Bitung

Dari Gambar 3 diatas menunjukkan bahwa untuk Kota Bitung percepatan maksimum gerakan tanah di batuan dasar (bed rock) pada probabilitas $2 \%$ terlampaui dalam 50 tahun atau setara dengan periode ulang 2500 tahun adalah sekitar 0,7 g. Penyebab terbesar disebabkan oleh adanya aktivitas dari West Sangihe Thrust atau penunjaman ganda laut Maluku yang menunjam ke arah barat dan tepat di depan sebelah timur Kota Bitung. Penyebab kedua terbesar adalah adanya gempa-gempa dangkal (shallow) yang cukup memberikan resiko yang cukup signifikan di sekitar wilayah Bitung. Kedua sumber gempa tersebut berada pada kedalaman dangkal yakni kurang dari $50 \mathrm{~km}$ dan mempunyai percepatan gempa di batuan dasar masingmasing yakni sekitar $0.6 \mathrm{~g}$ dan $0.5 \mathrm{~g}$.

Sedangkan sumber gempa dalam (deep) dan megathrust dari Subduksi Sulawesi Utara nilainya cukup kecil dibandingkan dengan kedua sumber gempa sebelumnya di atas dan mempunyai percepatan sekitar $0.3 \mathrm{~g}$ dan $0.2 \mathrm{~g}$. Dari nilainilai percepatan gempa di batuan dasar ini pada probabilitas terlampui $2 \%$ dalam 50 tahun menunjukkan bahwa Kota Bitung sangat rentan terhadap gempa-gempa merusak baik yang berada pada kedalaman dangkal maupun dalam.

Sumber gempa yang mempunyai laju rata-rata kejadian pertahun (annual rate of exceedance) terbesar adalah sumber gempa shallow background dan gempa-gempa dalam (deep background). Gempa-gempa yang diakibatkan oleh shallow background terjadi pada zona dangkal pada kedalaman 0$50 \mathrm{~km}$. Sedangkan gempa-gempa deep background berada pada 50 sampai $300 \mathrm{~km}$. Dari nilai annual rate of exceedance (laju rata-rata kejadian per tahun) kedua sumber gempa diatas hampir dapat dipastikan bahwa kejadian gempa pertahunnya terjadi hampir 5-6 kali dengan magnitudo lebih besar dari 5 Mw. Sementara sumber gempa megathrust akibat subduksi Sulawesi Utara dan fault (West Sangihe Thrust) kejadian pertahunnya sangat jarang akan tetapi kalau terjadi akan menghasilkan percepatan gerakan tanah yang sangat besar.

\section{KESIMPULAN DAN SARAN}

\section{Kesimpulan}

Dari hasil analisis respon spketra gempa untuk wilayah Bitung dan sekitarnya dapat disimpulkan sebagai berikut:

1. Percepatan gempa maksimum di batuan dasar Kota Bitung pada probabilitas $10 \%$ terlampaui dalam 50 tahun adalah sekitar 0.7 g. Nilai percepatan ini kontribusi terbesar berasal dari sumber gempa yang kedalamannya kurang dari $50 \mathrm{~km}$.

2. Wilayah Bitung dan sekitarnya mempunyai aktivitas tektonik yang cukup tinggi sebagai akibat dari adanya beberapa aktivitas penunjaman seperti penunjaman laut Maluku dan dan Subduksi Sulawesi Utara.

\section{Saran}

1. Perlu dilakukan penelitian yang lebih mendetail tentang sumber-sumber gempa yang ada di wilayah Bitung agar dalam pemodelan sumber gempa dapat lebih teliti.

2. Dari nilai hazard gempa yang diperoleh mengindikasikan bahwa wilayah Sulawesi Utara dan sekitarnya sangat rentan terhadap bahaya gempa, maka dalam pembuatan gedung atau sarana infrastruktur sangat diharapkan untuk selalu memperhitungkan faktor percepatan gempa. 


\section{DAFTAR PUSTAKA}

Gardner, J.K., Knopoff, L. 1974. Is the Sequence of Earthquakes in Southern California, with Aftershocks removed, Poissonian. Bulletin of the Seismological Society of America, Vol. 64, No. 5, pp. 1363-1367.

Gutenberg, B., Richter, C.F. 1944. Frequency of Earthquakes in California, Bulletin of the Seismological Society of America, Vol. 34, No. 4, pp. 185-188,

Hamilton, W.B. 1979. Tectonics of the Indonesian region: USGS Prof. Paper, 1078, 345 .

Irsyam, M; Hoedajanto, D; Kertapati K, E; Boen T, Petersen,D, M,; Dangkua, T, D. 2008. Usulan Revisi Peta Hazard Kegempaan Wilayah Indonesia Bandung, HATTI.

Stepp, J.C. 1973. Analysis of Completeness of the Earthquake Sample in the Puget Sound Area, NOAA Technical Report, ERL 267-ESL 30, pp. 16-28. Boulder, Colombia: NOAA.

Widiyantoro, S. 2007. Fisika dan Struktur Interior Bumi. Penerbit Badan Meteorologi dan Geofisika Jakarta.

Wiemar, S. 2001. A software package to analyze seismicity. ZMAP, Seismological Research Letters, 72(2), 373-382. 